\title{
12 Social Enterprise in Spain
}

\author{
From a Diversity of Roots to a \\ Tentative Typology of Models
}

\author{
Millán Díaz-Foncea, Esther Villajos, \\ Teresa Savall, Carmen Guzmán, \\ Francisco Javier Santos, Marta Solórzano- \\ García, Chaime Marcuello-Servós, Rafael \\ Chaves-Ávila and Carmen Marcuello
}

\section{Introduction}

This chapter's objective is to analyse the various perspectives on the concept of social enterprise (SE) as well as the different SE models existing in Spain. While the first major section presents the context and the main concepts related to the SE phenomenon in the country, the second one identifies and describes models of social enterprise.

\subsection{Understanding Concepts and Context}

In Spain, the term "social enterprise" has historically been linked to the organisations that promoted the social and labour integration of persons at risk of social and labour exclusion and other similar social activities. These organisations are recognised as part of the social economy, in accordance with the standpoint of European Union institutions (Monzón-Campos and Chaves-Ávila 2017). The fields in which the concept of social enterprise first emerged in Spain are probably academia and politics, which are more connected than field initiatives to debates and research in Europe.

At the beginning of the 1980s, different social organisations that had launched special programmes of training and labour integration, focusing on excluded people or people at risk of exclusion, experienced difficulties with regard to the subsequent social integration of their trainees. They then began to create labour initiatives as a follow-up of the training process they offered. These initiatives can be viewed as the predecessors of work-integration social enterprises (WISEs) in Spain, and they are considered as the country's first "social enterprises" (Vidal 1997; Puig Olle 1998; Álvarez 1999; Rojo Giménez 2000; García and Esteve 2007), although they did not obtain legal recognition until 2007 (Law 44/2007). ${ }^{1}$ Other initiatives that emerged during

DOI: $10.4324 / 9780429055140-12-14$ 
these years and can be linked to social enterprise in Spain include "sheltered-employment centres" (centros especiales de empleo; we will use the English acronym, SEC, hereafter), which dealt with the work integration of disabled people and gained legal recognition in 1982 (Law 13/1982 for the Social Integration of Disabled Persons), and social-initiative cooperatives, similar to Italian social cooperatives, which emerged to manage social services and cultural activities, were precariously financed by the government, and were finally recognised at the national level by Law 27/1999 on Cooperatives. ${ }^{2}$ These three types of organisation can be considered as predecessors of social enterprises in Spain, although they did not really self-identify with this concept, except maybe in the case of those belonging to the first type.

But despite the existence of these initiatives, the recognition of the concept of social enterprise at the general level did not come until 2006, when Ashoka-Spain selected its first fellows, increasing knowledge about social entrepreneurship and social-business activities among the media and thus among a broad sector of society. New consultancies and institutions are related to the understanding that social enterprises are a vehicle for social innovation and bring about solutions to social problems which neither the traditional market nor the public administration can provide.

In fact, the term "social enterprise" is still underused in Spain, and a debate still exists regarding its definition. A mix of perspectives on this concept, with different nuances, can be observed (European Commission 2020) and, following a tendency that Ashoka initiated, the term "social entrepreneur" is now used more frequently than that of "social enterprise". Social-economy entities also contribute to this debate and support the idea that some traditional social-economy organisations-and not only WISEs and SECs—should be recognised as social enterprises. This is the case of some agricultural cooperatives, with a long tradition in Spain, which have empowered people in the country's hinterland and were in many cases the only economic organisations in those areas.

Other business models have also recently emerged with the goals of overcoming the challenges of funding and increasing the viability of nongovernmental organisations (NGOs). Some NGOs started searching for a commercial approach to diversifying their funding sources, following a path that had been opened-although not in a very conscious way-by other NGOs in the mid-1990s.

Finally, the concept of social enterprise has also been used to refer to those social movements, including associations and other transitional movements, which took the leap from the social field to the business arena. They were aware of the need to professionalise the alternatives they proposed, and to give them economic viability to increase the dissemination of their principles and practices in the economic arena, so 
they acquired entrepreneurial characteristics. Likewise, other experiences originated in individual initiatives or informal movements that developed business activities and opened small shops emphasising fair, organic and local trade.

In sum, the debate about the concept of social enterprise is still open in Spain. This concept has roots in the social-economy sector, but organisations with an Anglo-Saxon perspective also use this term with increasing frequency. On the basis of the above analysis and of other works (Chaves-Ávila and Monzón-Campos 2018) about the various sources of the concept of social enterprise in Spain, four major groups can be highlighted within the existing range of organisations and businesses linked to this concept:

- organisations coming from the social-economy tradition (socialintegration cooperatives, sheltered-employment centres);

- organisations linked to social innovation and encouraged by platforms such as Ashoka;

- transitional movements seeking new business models in different areas (e.g., the solidarity economy, the "Som" movements ${ }^{3}$ );

- for-profit enterprises seeking to improve their social impact (B Corps, common-good economy, enterprises implementing social-responsibility practices).

\subsection{Identification of SE Models}

\subsubsection{Methodology and Data Collection Strategy}

We used the EMES ideal type of social enterprise (Defourny and Nyssens 2012) to classify social enterprises in Spain. With a view to obtaining a fuller picture of the SE phenomenon in the country, we added one indicator to each of the dimensions highlighted by EMES: the self-financing degree to the economic dimension; the focus on a social-transformation mission to the social dimension; and membership in external networks to the governance dimension. We also decided to somehow enrich the evaluation of the "economic risk", an important indicator of social enterprises' economic dimension: when applicable, the economic risk was also apprehended through the initial investment made by founding members.

Since no SE models, apart from that of work-integration social enterprise, are clearly identified in Spain, and no database or contact directory is available, we used a sector-based approach to construct our typology. We identified eight main economic sectors and then differentiated between two groups of organisations within each sector. Our approach was based on a brainstorming exercise involving the authors of this chapter and a review of the publications in the field; the resulting 
overview of the different groups of actors in the SE field was then submitted for feedback to social-economy practitioners.

We then assessed (on a scale from 0 to 2) the degree to which each of the twelve selected indicators (nine EMES indicators and three additional indicators) could be considered to be present or absent in the organisations belonging to each group: " 0 " refers to the absence of the considered element in most organisations in the group; " 1 " indicates that the element is observed in some organisations but not in a majority, or in most organisations but to a limited extent; and " 2 ", that the element is present in most organisations in the group. Results are shown in table 12.1 (see section 12.2.3).

Finally, on the basis of these results, we identified five major categories of social enterprise in Spain.

\subsubsection{Results: Analysis by Fields of Activity and Groups ${ }^{4}$}

\section{Work and Social Integration}

\section{GROUP 1: WORK-INTEGRATION SOCIAL ENTERPRISES (WISES)}

The characteristics of WISEs and the requirements they have to meet are defined by Law 44/2007. These characteristics and requirements are aligned with the social economy' principles and values: the enterprise's goal is the social integration of people at risk of social exclusion; the distribution of profit is limited; the promoter(s) and owner(s) is (are) one or more non-profit organisation(s); workers must be qualified by the Public Employment Service as being "at risk of social exclusion and unemployed"; the enterprise must participate in the market through the sale of goods and services, and this has to be its main source of income; and the enterprise must serve as a bridge between a situation of social exclusion/unemployment and the labour market.

In sum, WISEs fit all the requirements to be considered as social enterprises, except those related to governance. As far as the economic dimension is concerned, WISEs are conventional firms with a special qualification. They produce goods and services, mainly related to public services, and assume an economic risk. Regarding the social dimension, WISEs' main goal is the work integration of their target workers. They strive to change their social environment, and not just the situation of this group. The enterprise's main owner has to be a non-for-profit organisation. Finally, as regards governance, although WISEs can use the legal form of worker cooperative, most of them are limited-liability companies (only $8 \%$ are cooperatives), in which workers have a low decision-making power. WISEs are grouped in regional and national federations. 
204 Díaz-Foncea, Villajos, Savall, Guzmán et al.

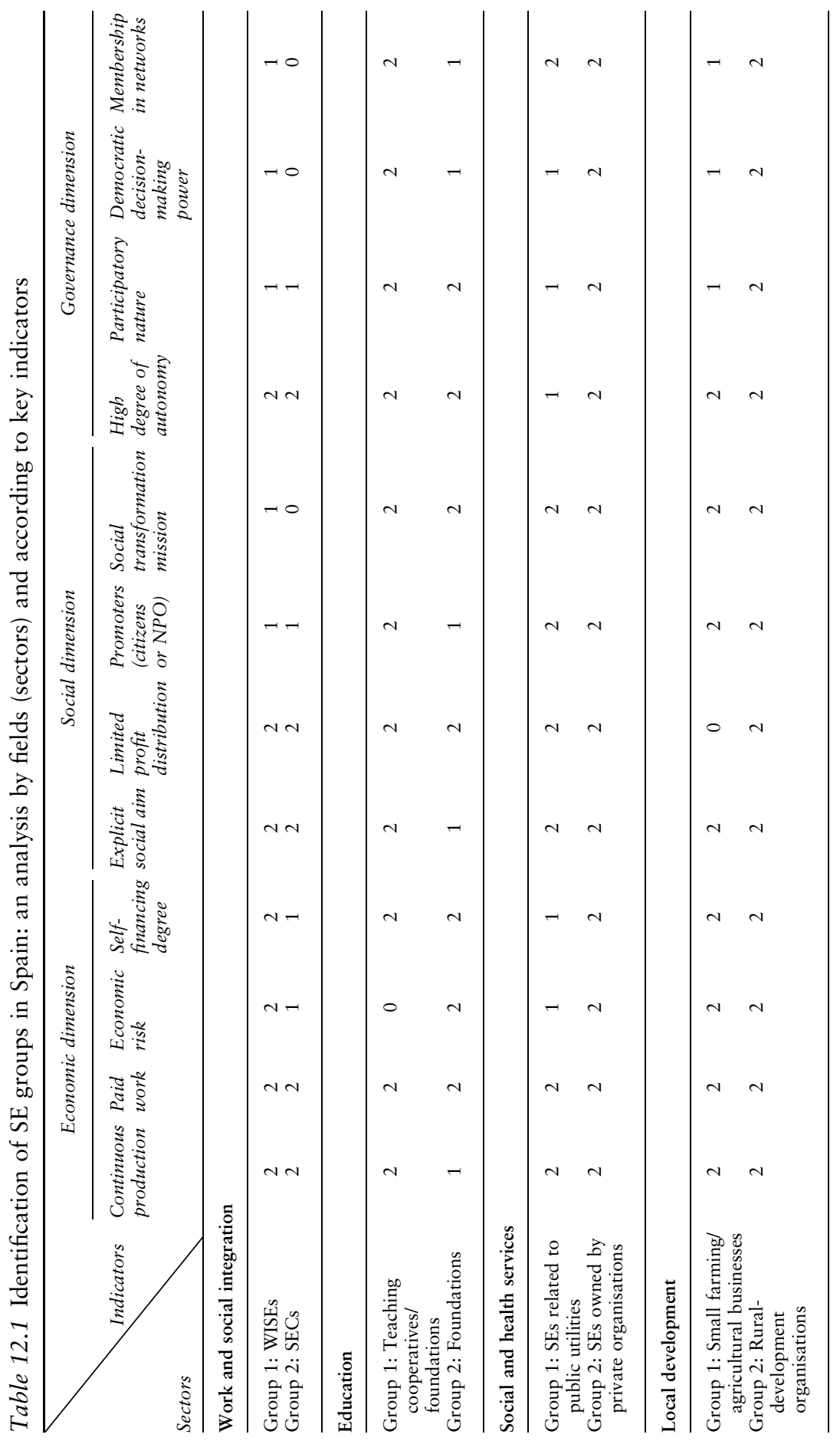


Spain 205

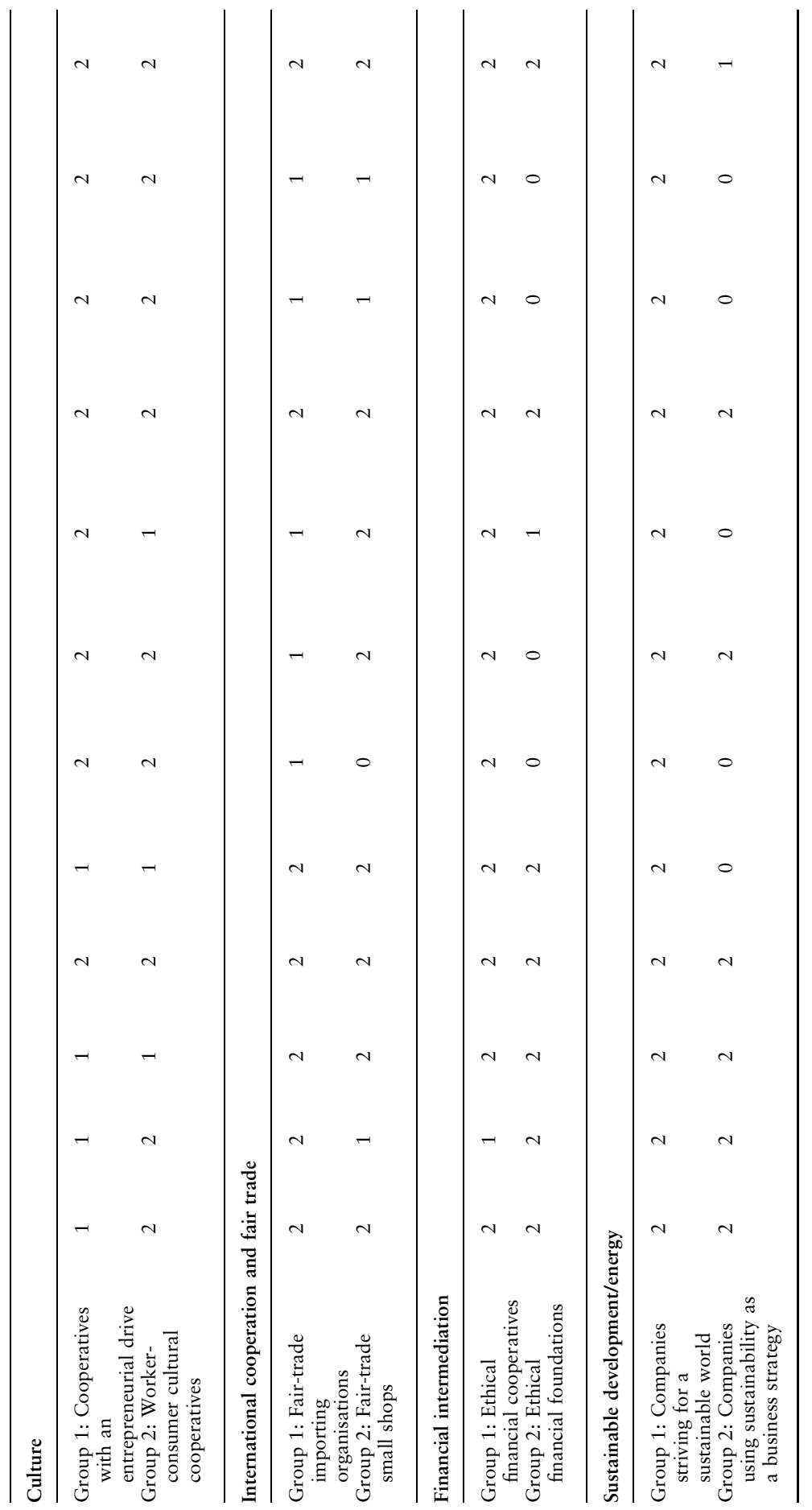


GROUP 2: SPECIAL-EMPLOYMENT CENTRES (SECS)

SECs constitute the legally recognised form of employment of disabled people. They are defined by Law LISMI 1982 as follows: at least 70\% of employees have to be legally recognised as being disabled (physical, mental or sensory disability); SECs can be promoted by the public or the private sector, and they can be for-profit or non-profit entities; they are market-oriented, although, due to their employees' low productivity, additional public and private funding is necessary to ensure the organisation's financial sustainability.

As regards the economic dimension, SECs have to obtain a significant share of their revenues from the sale of goods or services on the market. As far as the social dimension is concerned, SECs are primarily promoted by social movements, associations of parents of people with disabilities and people related to social services. Due to SECs' diversity in terms of economic goals, in some regions, the law differentiates between non-profit and for-profit SECs. Regarding the governance dimension, no requirements are imposed on SECs in terms of organisational or decision-making structure. The level of participation in the organisation thus depends on its organisational culture.

\section{Education}

GROUP 1: TRADITIONAL TEACHING COOPERATIVES AND FOUNDATIONS

Teaching cooperatives are schools managed by teachers or the students' parents, which appeared in Spain in the late 1960s, first in the Basque country and Catalonia. Currently, there are around 500 teaching cooperatives in Spain, representing between $10 \%$ and $12 \%$ of the privateschool network. These schools have a turnover of $€ 320$ million per year and $75 \%$ are secular.

Regarding indicators defining the ideal-typical social enterprise, we can point out that, in general, these enterprises meet the four indicators selected for each one of the three dimensions, except the indicator about the "economic risk" (economic dimension): these organisations' score for this indicator is very low because their main source of income is government support, granted through public agreements, for their education activities, and these organisations' members know well in advance if they are going to have the necessary number of pupils to obtain such support.

GROUP 2: FOUNDATIONS

Foundations in the field of education are non-profit organisations operating in the areas of training or research through the organisation of 
activities such as courses, free talks or conferences of general interest. They implement institutional mechanisms that promote exchanges and cooperation between all types of organisations and social-economy enterprises, as well as among industry players across the Spanish state and abroad.

Regarding indicators defining the ideal-typical social enterprise, we can point out that these entities fully meet seven of the twelve indicators selected for the three dimensions. They score medium for five indicators: they do not always rely on continuous production; they do not always meet a social need; some of them have been created by for-profit organisations; their decisions are significantly influenced by their main financer; and, finally, although they belong to networks related to education, their actual involvement in these networks is limited.

\section{Social and Health Services}

GROUP 1: SOCIAL ENTERPRISES RELATED TO PUBLIC UTILITIES

Social enterprises in this group arose when public-health institutions transferred to families most of the responsibility for the provision of care to patients with certain health problems-in particular mental health problems. ${ }^{5}$ Groups of promoters, usually consisting of relatives and health professionals working in fields linked to the illness, then founded associations to support these patients and their families.

Many of these social enterprises' activities focus on providing social services in cooperation with local, regional or national governments-an activity for which they receive payments. They also act as representatives of patients and relatives. The main sources of financing of these organisations consist of subsidies and public aid, but they also rely on aid from private entities, donations, membership fees and other resources of their own. Recently a need and a trend have been emerging among these organisations, which now look for clients outside the public administration to generate revenue for the company's productive activity. These social enterprises are usually non-profit organisations, legally registered either as associations or as foundations. With regard to staff, these organisations have both hired workers and volunteers, with the former outnumbering the latter.

\section{GROUP 2: SOCIAL ENTERPRISES OWNED BY PRIVATE ORGANISATIONS}

Social enterprises owned by private organisations are companies with a social objective, which aim to achieve a positive transformation of the society within which they develop their activities. They have a clear socio-economic model, linked to the company's mission, which prioritises the social objective over the financial one, but without forsaking 
the financial sustainability that is necessary for the survival of the organisation. Their income depends on their productive activity: customers pay for the services they receive. These social enterprises' financial resources do not come from subsidies or grants. As far as their legal form is concerned, they are registered as cooperatives or limited companies, and they are non-profit.

Whatever their legal form, they involve their stakeholders in their operational procedures, and their management system is based on respect for their employees, ethical behaviour and democratic, participatory and cooperative principles that promote community development. ${ }^{6}$

\section{Local/Rural Development}

GROUP 1: SMALL FARMING/AGRICULTURAL BUSINESSES

Small farming/agricultural businesses often use the legal forms of cooperative, private-liability company or self-employed worker. Their activities focus on ecological livestock production, eco-tourism and artisan work, and some of them are part of the recent movement for sustainable land stewardship and preservation of old customs and traditions.

These companies often combine a production activity with distribution. The main economic activity is the maintenance of traditional agriculture and traditional livestock farming, which respect the environment and avoid the costs, inconveniences and pressures usually imposed by large intermediaries. The key feature of these initiatives is their will to offer high-quality products and services at reasonable prices.

These firms ${ }^{7}$ insist on the idea of cooperation and mutual support among farmers, highlighting the fact that such synergies are crucial to face the hegemony of multinational food chains. Therefore, these organisations have initiated an association movement. They implement good working and social practices, based on respect of human and social rights. The farming model is also based on respect for all the actors involved in the process of production and distribution, who all receive fair and equitable treatment. The participative and sustainable business model adopted is integrated with the surrounding society, and it seeks to contribute to making an equitable and healthy world possible for all.

\section{GROUP 2: RURAL-DEVELOPMENT ORGANISATIONS}

Rural development is a process bringing about positive changes in rural areas, which can improve the lives of people taking part in the movement as well as the quality of life of society as a whole. Rural-development organisations help the communities achieve food self-sufficiency in a sustainable and environmental-friendly way, while preserving their cultural identity and the integrity of resources. The sustainable, integrated 
and human rural development promoted by these organisations involves the management of resources in an economically viable, environmentally healthy, socially just and culturally acceptable way.

These initiatives provide services to people on a continuous basis and their financial resources come from trading activities, public subsidies and voluntary resources. The level of economic risk they support is very high as their financial viability depends entirely on the efforts of their members to secure adequate resources to support the organisation's social mission. They combine monetary and non-monetary resources, and voluntary and paid workers.

These initiatives, which are launched by a group of citizens or civilsociety organisations, pursue a goal of social transformation. They have an explicit social aim, namely to improve the lives of people involved in the movement, as well as the quality of life in society as a whole. Because of the social principles upon which they are built and of the social objective they pursue, their distribution of benefits is limited by internal rules. These social principles are also reflected in their governance model: they have a high degree of autonomy, their decision-making process is democratic, their nature is highly participatory, and they involve the rural communities in their activities. ${ }^{8}$

\section{Culture}

GROUP 1: COOPERATIVES WITH AN ENTREPRENEURIAL DRIVE

Cooperatives with an entrepreneurial drive in the field of culture are a kind of cooperative that is officially recognised by the laws of two Spanish regions only, namely Andalusia and Cantabria. These enterprises are similar to the "umbrella companies" which are well known in other countries, like the UK. These companies are intermediate platforms which act as an employer, entering a business-to-business contract with an employment agency.

These cooperatives are formed by experienced professionals with knowledge in social enterprises and unemployed workers looking for a job. Both groups become worker members of the cooperative, which offers them technical and managerial support. Furthermore, these entities "channel" the members' entrepreneurial initiatives with the aim of conducting activities in the market.

These entities meet eight of the twelve indicators selected. They completely meet the four indicators of the governance dimension and, regarding the social dimension, the only indicator in which they show a medium level is that about the explicit social aim. However, the most important weak points are in the economic dimension: except for the indicator on financing, for which they score high, they show a medium level of compliance with all the indicators of the economic dimension. Indeed, these enterprises, since they mostly provide technical and managerial 
support, can be considered as having only a medium level of continuous production, and the salaries are mostly symbolic or are covered by other organisations involved in the initiative. Moreover, members can usually not afford a very high initial investment (medium level of economic risk).

GROUP 2: WORKER-CONSUMER CULTURAL COOPERATIVES

Worker-consumer cultural cooperatives are very recent and innovative initiatives in the cultural field. Unlike initiatives in the previous group, in which all members are also necessarily workers, worker-consumer cultural cooperatives offer their customers the possibility to become members and to receive certain advantages (to which non-member consumers are not entitled). This is the reason why they are considered as mixed cooperatives: they are both worker and consumer cooperatives.

These entities score high for nine of the twelve indicators selected. They fully meet the four indicators of the governance dimension. They also achieve a high performance in the economic dimension, in which the only indicator for which they show a medium level of compliance is that related to the "economic risk"; in this respect, they implement mechanisms, such as the inclusion of their customers as collaborators/ members, in order to "spread" the level of risk among the stakeholders. Finally, regarding the social dimension, these entities have a limited profit distribution, and they are launched by a group of citizens; they thus score high for these two indicators. But their offer of culture-related services can be considered as an only "moderately" explicit social aim, and they can also be considered as only partially pursuing social transformation, since their main aim is to promote culture and create jobs.

\section{International cooperation/fair trade}

\section{GROUP 1: FAIR-TRADE IMPORTING ORGANISATIONS}

Fair-trade importing organisations ${ }^{9}$ import all kinds of fair-trade products from Southern countries. They contact producers directly and manage the import logistics; sometimes, they transform the raw materials (e.g., coffee) into the final product; they help local farmers in the south by providing them with training and financial support; they carry out education and advocacy campaigns; and they work with corporate (physical or on-line) shops to sell the products.

As far as the economic dimension is concerned, these organisations have a continuous production; they operate in the market and assume an economic risk. Their main source of income is the sale of products. Regarding the social dimension, these initiatives have a clear social aim, namely to ensure fair wages for the producers, but the extent to which they meet the indicators relating to the limitation imposed on profit 
distribution and to the "citizen-initiated nature" varies from one organisation to the other. Finally, as regards the governance dimension, these organisations have a high degree of autonomy, and although they usually evolve towards the implementation of participatory mechanisms to give voice to both workers in the North and producers in the South, not all organisations have a democratic way of making decisions.

\section{GROUP 2: FAIR-TRADE SMALL SHOPS}

These are the most typical organisations related with the distribution of fair-trade products. They are usually small, but their managers and promoters have a strong commitment to fair-trade activities.

As far as the economic dimension is concerned, these organisations' main source of income is the sale of fair-trade products (94\% approximately); they also usually receive subsidies or donations. They bear significant economic risk and they rely on volunteers, although some of them also have paid workers, mainly for administrative tasks. Regarding their social dimension, they have a clear commitment to improving the living conditions of producers from the South. They are launched by a group of citizens or a civil-society organisation. However, in most organisations, there is no rule to avoid or limit profit distribution. As regards the governance dimension, these small businesses are highly autonomous and are part of networks, but their decision-making processes have only a medium level of participatory nature and democratic decision-making.

\section{Financial Intermediation}

\section{GROUP 1: ETHICAL FINANCIAL COOPERATIVES}

Ethical financial cooperatives are initiated by groups of citizens who want their savings to finance projects that are socially responsible and sustainable. These citizens thus come together and set up their own entity, guaranteeing the responsible destination of the money in the financial intermediation services.

Regarding the economic dimension, these entities have a continuous economic activity in the market; the people involved in these organisations are usually volunteers or workers with only a symbolic salary; the members cannot afford any initial investment, so they try to invest only in selfsustainable projects; and these companies are self-financed through their financial products. Regarding the social-dimension indicators, entities in this group pursue an explicit social aim of creating a financial system based on the values shared by their initiators and members; they do not distribute profits, as all profits are reinvested in the organisation's objective; and their social-transformation objective can be considered as strong, since they want to change the economic system through the financial system. 


\section{Díaz-Foncea, Villajos, Savall, Guzmán et al.}

Finally, regarding governance factors, these initiatives are completely independent from any other entity; they have a highly participatory nature; their decision-making process is democratic and not based on capital ownership; and their participation in networks is high.

\section{GROUP 2: ETHICAL FINANCIAL FOUNDATIONS}

This group includes financial-intermediation firms that only support sustainable and socially responsible projects but do not pursue a socialtransformation goal. These entities are thus similar to conventional banks in terms of organisation and management.

Regarding the economic dimension, these initiatives develop an economic activity and have a continuous production; their employees receive a salary for their work; they invest in sustainable projects, but the level of economic risk they bear remains high; and they are self-financed through their financial products. Regarding the social dimension, these initiatives have an explicit social aim-namely financing sustainable projects; they distribute profits as any other commercial bank; and they are only rarely really launched by a group of citizens. In terms of governance indicators, enterprises in this group have a high degree of autonomy; their participatory nature is low; their decision-making process is not democratic; and their participation in networks is high.

\section{Sustainable Development/Energy}

\section{GROUP 1: COMPANIES STRIVING FOR A SUSTAINABLE WORLD}

This group consists of companies that strive for a sustainable world; they have been emerging mainly since $2010 .^{10}$ Two major kinds of initiative can be distinguished in this group. The first one corresponds to energy companies aiming to spread and promote the use of renewable energy and to develop a participatory energy model in setting prices-namely consumer cooperatives or "energy cooperatives" (Zaad 2012). The second one consists of companies engaged in organic farming and environmental protection, whose purpose is to convert conventional farms to the practice of sustainable agriculture (e.g., integrated organic production, fight against erosion).

These initiatives produce and distribute green energy or organic food on a continuous basis; they do rely on paid work; the economic risk is supported by the members; and they are self-financing. Entities in this group have an explicit objective of social transformation; they have a limited profit distribution (they reinvest their profit in sustainable projects); and they are initiatives launched by a group of citizens. Finally, they have a high degree of autonomy and a highly participatory nature; their decision-making process is democratic and not based on capital ownership; and their participation in networks is high. 
This group consists of companies that use sustainability (e.g., green energy or organic-food distribution) as a business strategy to attract customers, without having the specific purpose of striving for a sustainable society. These companies describe themselves as "social firms", but the analysis of their functions, structure and activity shows that their business model is close to the capitalist model.

These companies have a continuous production and paid workers and they are self-financed. The founding partners make an initial investment in the start-up stage of the firm and bear a high economic risk. In general, entities in this group are initiatives launched by a group of citizens, but they do not have an explicit social aim and they do not impose limitations on profit distribution. Finally, these organisations have a high degree of autonomy, but their participatory nature is very low; their decision-making process is based on capital ownership; and membership in networks can be considered to be of a medium level, as they sometimes belong to associations and networks related to the social economy and social entrepreneurship in order to take advantage of their support.

\subsubsection{Identification of SE Models}

Table 12.1 summarises the characteristics of the various groups of social enterprise identified in Spain in terms of correspondence with the indicators defining the ideal-typical social enterprise (i.e., the nine EMES indicators and the three indicators that have been added to analyse the phenomenon of social enterprise in Spain). However, the number of items presented in the table made it difficult to discern models, and in order to generate a more usable set of data, we grouped the four indicators in each of the three major dimensions (economic, social and governance dimensions), and thus obtained a score comprised between 0 and 8 points for each dimension. ${ }^{11}$ We are aware that such grouping entails a "simplification" that could hide nuances among groups; however, we accept this problem with a view to operationalising our data and to offering a first proposal of SE typology.

In the analysis of data, we considered that, for each of the three dimensions, 7-8 points corresponded to a high level; 5-6 points, to a medium level; and less than 5 points, to a low level. Of course, we acknowledge the fact such classification is closer to the idea of a continuum than to a typology stressing structural differences among SE models. However, instead of basing our analysis on a single key criterion (like the degree of market reliance, for instance), we combined a set of significant indicators and gave a similar importance to all three SE key dimensions. Such an integrated "multi-criteria" basis allowed us to identify five SE categories (see table 12.2) according to their overall "compliance" with the enlarged EMES framework. 
214 Díaz-Foncea, Villajos, Savall, Guzmán et al.

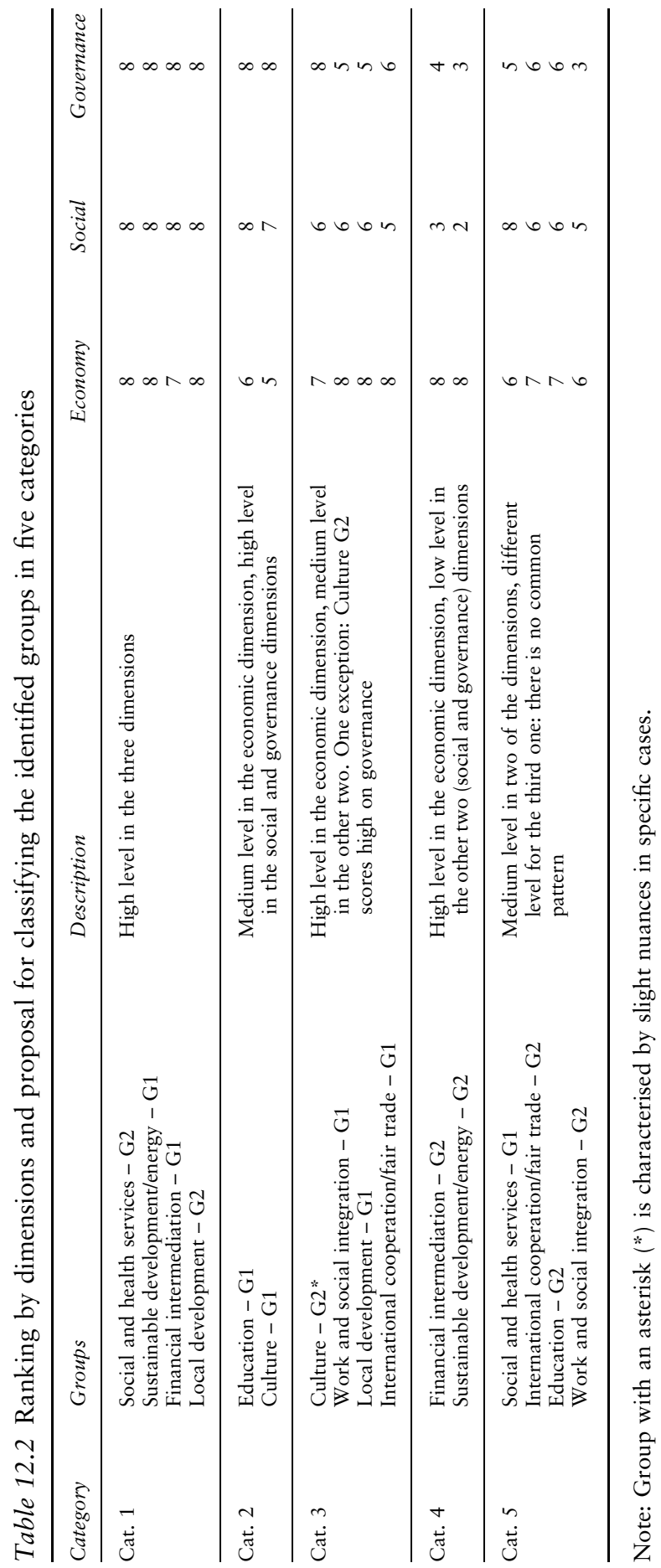




\section{Conclusion}

In the present work, we attempted to identify models of social enterprise in Spain. We first reviewed the origins of social enterprises and the existing approaches from a theoretical point of view. We identified four "matrices" of social enterprise in Spain: (1) organisations whose origins are to be found in the social-economy tradition; (2) organisations linked to social innovation and encouraged by platforms such as Ashoka; (3) transitional movements seeking new business models in different areas; (4) for-profit enterprises seeking to improve their social impact.

In a second stage, we carried out empirical observations in the field. On this basis, we identified five different categories of social enterprise in Spain, in terms of correspondence with the various indicators retained to characterise social enterprises (nine EMES indicators and three additional ones).

To conclude, it appears that, although the rise of the concept of social enterprise in Spain is strongly related with the establishment of organisations inspired by the Anglo-Saxon tradition and with the discussions about the concept in the EU, the characteristics of the organisations must be mainly related to the way of working of social-economy organisations. Indeed, Spain is one of the European countries where the social economy has been most widely acknowledged and promoted, and long before the emergence of the SE notion. Further research should look more precisely at the types of relations that will be developed between the "SE stream" and the whole social economy. Their respective roles in the design and implementation of public policies would also deserve researchers' attention.

\section{Notes}

1 Law 44/2007, on work-integration enterprises (Ley 44/2007, de 13 de diciembre, para la Regulación del Régimen de las Empresas de Inserción).

2 Law 27/1999, on cooperatives (Ley 27/1999, de 16 de julio, de cooperativas).

3 The term "Som" could be translated as "we are" and comes from the name of the first renewable energy cooperative in Spain, "Som Energia", created in 2010. Since then, a new generation of consumer cooperatives have emerged using the term "Som" as a reference to citizen engagement in consumption: Som Conexion (telecommunications), Som Mobilitat (transport), Som Alimentació (supermarkets), etc. The concept refers to companies born from the mobilisation of civil society in search of economic alternatives and social transformation.

4 The length of this chapter being limited, the description of the different groups presented here is quite succinct; a more extensive analysis of each sector and group can be found in Díaz-Foncea et al. (2017).

5 Representative examples of this group are AFES (https://saludmentalafes.org/) and FUNCASOR (http://funcasor.org/).

6 Representative examples of this group are Fundación Espriu (Grupo ASISALavinia and Group Assistència-SCIAS) (http://www.fundacionespriu.coop/) and COS, Cooperativa de salut (http://www.cos.coop/es/). 


\section{Díaz-Foncea, Villajos, Savall, Guzmán et al.}

7 Representative examples of this group are L'Olivera (http://www.olivera.org/ php/index.php) and Huertos de Soria (https://www.huertosdesoria.org/).

8 Representative examples of this group are CIFAES-URPF en Tierrra de Campos (https://coop57.coop/es/entidad/cifaes-universidad-rural-paulofreire-en-tierra-de-campos) and Heliconia (https://www.heliconia.es/).

9 Eleven importing organisations exist in Spain: Adsis Equimercado, Alternativa 3, Espanica, Fundación COPADE, Fundación Vicente Ferrer, IDEAS, Intermón Oxfam, Mercadeco, SETEM, Taller de Solidaridad and Xarxa de Consum Solidari.

10 Examples of companies striving for a sustainable world include Som Energia, S. Coop. and other similar renewable-energy cooperatives.

11 As explained in section 12.2.1, we assessed the degree to which each of the twelve selected indicators could be considered to be present or absent in the organisations belonging to each group on a scale from 0 to 2 .

\section{References}

Álvarez, M. I. (1999) "Las Empresas de inserción social como nueva forma de organización empresarial. Especial referencia a su régimen jurídico", CIRIEC-España, Revista de economía pública, social y cooperativa, No. 31, pp. 47-84.

Chaves-Ávila, R. \& Monzón-Campos, J. L. (2018) "La economía social ante los paradigmas económicos emergentes: innovación social, economía colaborativa, economía circular, responsabilidad social empresarial, economía del bien común, empresa social y economía solidaria”, CIRIEC-España, Revista de economía pública, social y cooperativa, No. 93, pp. 1-34.

Defourny, J. \& Nyssens, M. (2012) "El enfoque EMES de la empresa social desde una perspectiva comparada", CIRIEC-España, Revista de economía pública, social y cooperativa, No. 75, pp. 7-34.

Díaz-Foncea, M., Marcuello, C., Marcuello, C., Solorzano, M., Navío, J., Guzmán, C., de la O Barroso, M., Rodríguez, M. J., Santos, F. J., Fisac, R., Alguacil, P., Chaves, R., Savall, T. \& Villajos, E. (2017) "Social Enterprise in Spain: A Diversity of Roots and a Proposal of Models", ICSEM Working Papers No. 29, Liege: The International Comparative Social Enterprise Models (ICSEM) Project.

European Commission (2020) Social Enterprises and Their Ecosystems in Europe. Updated Country Report: Spain (authors: Díaz, M., Marcuello, C. \& Nogales, R.), Luxembourg: Publications Office of the European Union. Available HTTP: https://europa.eu/!Qq64ny.

García, A. \& Esteve, M. (2007) "Las Empresas de Inserción en España: normativa y características", CIRIEC-España, Revista de economía pública, social y cooperativa, No. 59, pp. 153-178.

Monzón-Campos, J. L. \& Chaves-Ávila, R. (2017) Recent Evolutions of the Social Economy in the European Union, Brussels: European Economic and Social Committee.

Puig Olle, A. (1998) "Las empresas de inserción. El papel de las fundaciones y las asociaciones en la creación de las empresas”, REVESCO: Revista de Estudios Cooperativos, No. 65, pp. 69-71. 
Rojo Giménez, C. (2000) "Empresas de inserción en Castilla y León”, CIRIECEspaña, Revista de economía pública, social y cooperativa, No. 36, pp. 97-115.

Vidal, I. (1997) “Associacions i inserció social pel treball a l'Estat espanyol”, Nexe, Quadern d'autogestió i economia cooperativa, Vol. 0, pp. 89-99.

Zaad, M.-H. (2012) "Cooperativas de producción, distribución y consumo de electricidad en España en el primer tercio del siglo XX. Un análisis económico", Simposio Internacional Globalización, innovación y construcción de redes técnicas urbanas en América y Europa, 1980-1930, Universidad de Barcelona, January 23-26, 2012. 